ORIGINAL ARTICLE / ARTIGO ORIGINAL

Falls among the elderly: risk factors in a population-based study

\title{
Quedas em idosos: fatores associados em estudo de base populacional
}

lara Guimarães Rodrigues', Gustavo Pereira Fraga", Marilisa Berti de Azevedo Barros'

\begin{abstract}
Purpose: The aim of the present study was to identify factors associated with the occurrence of falls among elderly adults in a population-based study (ISACamp 2008). Methods: A population-based cross-sectional study was carried out with two-stage cluster sampling. The sample was composed of 1,520 elderly adults living in the urban area of the city of Campinas, São Paulo, Brazil. The occurrence of falls was analyzed based on reports of the main accident occurred in the previous 12 months. Data on socioeconomic/demographic factors and adverse health conditions were tested for possible associations with the outcome. Prevalence ratios (PR) were estimated and adjusted for gender and age using the Poisson multiple regression analysis. Results: Falls were more frequent, after adjustment for gender and age, among female elderly participants (PR $=2.39 ; 95 \%$ confidence interval $(95 \% \mathrm{CI}) 1.47-3.87$ ), elderly adults (80 years old and older) $(\mathrm{PR}=2.50 ; 95 \% \mathrm{CI} 1.61-3.88)$, widowed (PR $=1.74 ; 95 \% \mathrm{CI} 1.04-2.89)$ and among elderly adults who had rheumatism/arthritis/arthrosis $(\mathrm{PR}=1.58 ; 95 \% \mathrm{CI} 1.00-2.48)$, osteoporosis $(\mathrm{PR}=1.71 ; 95 \% \mathrm{CI} 1.18-2.49)$, asthma/bronchitis $/$ emphysema $(\mathrm{PR}=1,73 ; 95 \% \mathrm{CI} 1.09-2.74)$, headache $(\mathrm{PR}=1.59 ; 95 \% \mathrm{CI} 1.07-2.38)$, mental common disorder $(\mathrm{PR}=1.72$; $95 \% \mathrm{CI} 1.12-2.64)$, dizziness $(\mathrm{PR}=2.82$; $95 \% \mathrm{CI} 1.98-4.02)$, insomnia $(\mathrm{PR}=1.75 ; 95 \% \mathrm{CI} 1.16-2.65)$, use of multiple medications (five or more) $(\mathrm{PR}=2.50 ; 95 \% \mathrm{CI} 1.12-5.56)$ and use of cane/walker $(\mathrm{PR}=2.16$; 95\%CI 1.19 -3,93). Conclusion: The present study shows segments of the elderly population who are more prone to falls through the identification of factors associated with this outcome. The findings can contribute to the planning of public health policies and programs addressed to the prevention of falls.
\end{abstract}

Keywords: Aging. Aged. Accidental falls. Health surveys. Cross-sectional studies. Risk factors

ISchool of Medical Sciences, Department of Public Health, Universidade Estadual de Campinas - Campinas (SP), Brazil. "School of Medical Sciences, Discipline of Trauma Surgery, Universidade Estadual de Campinas - Campinas (SP), Brazil. Corresponding author: lara Guimarães Rodrigues. Departamento de Saúde Coletiva, Faculdade de Ciências Médicas, Universidade Estadual de Campinas. Rua Tessália Vieira de Camargo, 126, CEP: 13084-971, Campinas, SP, Brasil. E-mail: iaraguimar@gmail.com Conflict of interests: nothing to declare - Financing source: National Council of Technological and Scientific Development (CNPq), Process n. 409747/2006-8, Municipal Secretariat of Health of Campinas, Secretariat of Health Surveilance of the Ministry of Health, Coordination for the Improvement of Higher Education Personnel (CAPES). 
RESUMO: Objetivo: Identificar fatores associados à ocorrência de quedas em idosos, em estudo de base populacional (ISACamp 2008). Métodos: Trata-se de estudo transversal, com amostra tomada por conglomerados em dois estágios, totalizando 1.520 idosos residentes na área urbana do município de Campinas, São Paulo. Foram analisadas as ocorrências de quedas, relatadas como o principal acidente sofrido nos últimos 12 meses, segundo variáveis socioeconômicas, demográficas e de morbidades. Foram estimadas razões de prevalências (RP) ajustadas para idade e sexo por meio de regressão múltipla de Poisson. Resultados: Foram identificados com maior ocorrência de quedas, após ajuste por idade e sexo, os idosos do sexo feminino ( $\mathrm{RP}=2,39$; intervalo de confiança de $95 \%$ (IC95\%) 1,47 - 3,87), os mais idosos (80 anos e mais) ( RP = 2,50; IC95\% 1,61 - 3,88), os viúvos ( $\mathrm{RP}=1,74$; IC95\% 1,04-2,89) e os idosos que apresentavam reumatismo/artrite/artrose (RP = 1,58; IC95\% 1,00 - 2,48), osteoporose ( $\mathrm{RP}=1,71$; IC95\% 1,18 - 2,49), asma/bronquite/enfisema ( RP = 1,73; IC95\% 1,09 - 2,74), dor de cabeça ( $R P=1,59$; IC95\% 1,07 - 2,38), transtorno mental comum ( $R P=1,72$; IC95\% 1,12 - 2,64), tontura ( $R P=2,82$; IC95\% 1,98 - 4,02), insônia ( $R P=1,75$; IC95\% 1,16-2,65), uso de muitos medicamentos (cinco ou mais) $(\mathrm{RP}=2,50$; IC95\% 1,12 - 5,56) e uso de bengala/andador (RP = 2,16; IC95\% 1,19-3,93). Conclusão: Por meio da identificação desses fatores, o presente estudo aponta os segmentos de idosos mais susceptíveis às quedas e, dessa forma, pode contribuir para o planejamento de políticas públicas e programas de saúde voltados à prevenção de quedas e redução de suas consequências.

Palavras-chave: Envelhecimento. Idoso. Acidentes por quedas. Inquéritos epidemiológicos. Estudos transversais. Fatores de risco

\section{INTRODUCTION}

The increasing proportion of elderly people in the Brazilian population brings up the need to analyze and discuss the main impairing events that affect this age group ${ }^{1}$. Among these events, the occurrence of falls is relevant, since it has the potential of causing serious risks to health and to the life of the elderly; therefore, it is a very frightening situation ${ }^{1}$.

In Brazil, in 2010, 10,425 deaths were caused by falls, out of which $65.2 \%$ involved elderly people ${ }^{2}$. It is estimated that the Unified Health System (SUS), in Brazil, spent approximately R \$ 57.61 million with hospitalizations caused by falls in 2009, and in 2006 this amount was of R\$ 49 million ${ }^{2}$.

The fall results from the loss of postural balance, and it can be related to the sudden failure of neural and osteoarticular mechanisms involved in postural maintenance ${ }^{3}$. The frequency of falls increases significantly with the biological changes associated with age. With aging, the structure and function of skeletal muscles change. In terms of structure, muscle mass decreases because the number and the size of muscle fibers decline after the end of adulthood ${ }^{3}$. The loss of muscle mass and, consequently, muscle strength, is directly 
related with the reduction of mobility and impairment in physical performance, which contributes with the increasing risk of falls ${ }^{4}$.

conducted in different countries point out to the relevance of falls among elderly people, and detect annual frequencies ranging from $6.5 \%$ to $42 \%$, depending on the country and on the adopted methods for collecting information ${ }^{5,6}$.

Factors related to falls have been classified as intrinsic, which result from physiological changes related to aging, diseases and effects of medicines, and as extrinsic, which are related to circumstances and environmental conditions ${ }^{7}$.

Several sociodemographic factors ${ }^{1,8,9}$ and those related to housing conditions, family arrangements $^{1,10,11}$, diseases ${ }^{1,9}$ and visual and physical impairment ${ }^{1,11}$ have been associated with falls. Indicating factors that are associated with the occurrence of falls among the elderly is a relevant task, since it can contribute with subsidies for public policies and health programs addressed to preventing accidents and reducing their consequences ${ }^{1,12}$.

Considering the serious damage that falls can cause for the health of the elderly, besides their social and economic implications, the objective of this study was to identify factors associated with the occurrence of falls among elderly people living in the city of Campinas, São Paulo.

\section{METHODS}

This is a cross-sectional, population-based study conducted with a sample of noninstitutionalized elderly people (60 years old or more), living in an urban area in the city of Campinas, São Paulo. In 2008, the city had a little more than 1 million inhabitants, and 11\% of them were elderly people (60 years old or more). The data in this study are part of the health household survey (ISACamp 2008), conducted from February, 2008, to April, 2009. The survey aimed at obtaining information from several health dimensions regarding three age-related domains: adolescents (10 - 19 years old), adults (20 - 59 years old) and elderly people (60 years old or older).

The minimum number of people to compose the sample of each domain was established by considering the estimation of a $50 \%$ proportion, with $95 \%$ confidence interval $(95 \% \mathrm{CI})$, sampling error ranging between 4 and 5 percentage points, and design effect estimated at 2 . Therefore, a minimum number of 1,000 interviews was established for each age domain.

The survey sample was obtained by probability sampling procedures, in two-stage clusters: census and household sectors. In the first stage, 50 census sectors were raffled with probability proportional to size (number of households). For these 50 raffled sectors, households were updated in order to enable a posterior raffle. In the second stage, in order to reach the necessary sample size, 2,150, 700 and 3,900 households were independently raffled to obtain the minimum number of adolescents, adults and elderly participants, respectively. 
Information was obtained by a structured questionnaire, which was applied by trained and supervised interviewers. Inclusion criteria were: being at least 60 years old and accepting to answer the questionnaire, by signing the informed consent form.

In cases of elderly people with mental disorder, stroke sequels or any another reason that prevented participants from answering the questionnaire, a family member was requested to help with data collection. The analyzed variables were:

- Occurrence of falls reported as the main accident in the past 12 months obtained by the questions: "Were you involved in any kind of accident in the past 12 months?" (and the following was mentioned to the interviewee: traffic accident, falls, burns, events at home, at work etc.) and "Which was the main accident you were involved in in the past 12 months?".

- Other analyzed variables about falls reported as being the main accident in the past 12 months: place of occurrence; whether or not it caused limitations in daily activities and for how many days; whether or not the person was bedridden, and for how many days; and if the person needed medical care because of the fall.

- Socioeconomic and demographic variables: sex, age, marital status, schooling years, paid occupation, monthly per capita family income in minimum wages and type of household.

- Chronic morbidities, reported as being diagnosed by a doctor or other health professional: hypertension, diabetes, tumor/cancer, rheumatism/arthritis/arthrosis, osteoporosis, asthma/bronchitis/ emphysema, tendinitis/repetitive strain injury, and the total number of reported chronic diseases among those in the checklist.

- Health problems/symptoms: frequent headache, backache, dizziness, insomnia, and number of reported health problems among those in the checklist

- Common mental disorder (CMD), assessed by the Self Reporting Questionnaire (SRQ 20), with cutoff point of 6 or more ${ }^{13}$.

- Number of medications used in the past three days.

- Use of cane/walker and wheelchair.

The survey data were typed into a data base developed with the software EpiData 3.1 (Epidata Association, Odense, Denmark), and were submitted to an evaluation of consistency. For the analyses in this study, estimates were produced with $95 \% \mathrm{CI}$. The associations between variables and the falls that occurred in the past 12 months were analyzed by the $\chi^{2}$ test. Besides, simple regression and Poisson multiple regression were used to estimate crude and adjusted prevalence ratios (PR) for sex and/or age.

The analyses were conducted with the software Stata 11.0 (Stata Corp, College Station, United States) and used svy commands which incorporate the necessary weights according to sampling design.

The project of this study was approved by the Ethics Committee of the School of Sciences at Universidade Estadual de Campinas, report n. 079/2007. 


\section{RESULTS}

Among the selected households to obtain the sample of elderly people, there was a $6.5 \%$ loss, due to the impossibility of finding a resident or because the resident refused to describe the individuals living in that household. Out of the elderly people who were selected from the households, and were supposed to be interviewed, $2.3 \%$ refused to participate. Therefore, 1,520 elderly people were analyzed in this study.

From the studied population, $59.5 \%$ were female, with mean age of 69.9 years old; $6.5 \%$ reported falls as being the main accident in the past 12 months. After adjustment for age and/ or sex, the main occurrences of falls were observed among female participants ( $\mathrm{PR}=2.39$; $95 \% \mathrm{CI} 1.47-3.87$ ), older elderly people (80 years old or more) $(\mathrm{PR}=2.50 ; 95 \% \mathrm{CI} 1.61-3.88)$ and widow(ers) $(\mathrm{PR}=1.74 ; 95 \% \mathrm{CI} 1.04-2.89)$ (Table 1).

Among chronic diseases, the associations deriving from multiple analyses were: rheumatism/arthritis/arthrosis ( $\mathrm{PR}=1.58 ; 95 \% \mathrm{CI} 1.00-2.48)$, osteoporosis $(\mathrm{PR}=1.71$; $95 \% \mathrm{CI} 1.18-2.49)$ and asthma/bronchitis/emphysema (PR $=1.73 ; 95 \% \mathrm{CI} 1.09-2.74)$. With regard to other health issues, significant associations with falls were observed with: headache $(\mathrm{PR}=1.59 ; 95 \% \mathrm{CI} 1.07-2.38)$, dizziness ( $\mathrm{PR}=2.82 ; 95 \% \mathrm{CI} 1.98-4.02)$, insomnia $(\mathrm{PR}=1.75 ; 95 \% \mathrm{CI} 1.16-2.65)$ and $\mathrm{CMD}(\mathrm{PR}=1.72 ; 95 \% \mathrm{CI} 1.12-2.64)$. The occurrence of falls was increasing according to the number of morbidities and number of reported health problems, even after adjustments (Table 2). Besides, a significant association was observed between falls and the higher number of used medications (five or more) ( $\mathrm{PR}=2.50 ; 95 \% \mathrm{CI} 1.12-5.56)$ and use of cane or walker (PR $=2.16$; 95\%CI $1.19-3.93$ ) (Table 3 ).

It was possible to observe that elderly people fell mostly in their houses (64\%), followed by occurrences in the street (26\%). Among the elderly who reported falls as the main accident they were involved in in the past 12 months, $56.7 \%$ limited their daily activities, being $57.4 \%$ for three days or longer; $58.6 \%$ were bedridden, being $58.8 \%$ for three days or longer; and $71.2 \%$ required medical care because of the fall (Table 4 ).

\section{DISCUSSION}

The occurrence of falls reported as the main accident in the past 12 months was of $6.5 \%$. This frequency is similar to that observed in the study by Gang et al. ${ }^{5}$, conducted in Beijing, and inferior to the mean found in studies assessing the occurrence of falls, regardless of their severity ${ }^{1,9}$. This study considered only those falls that were considered to be the main accident the person was involved in in the past 12 months, so the most severe falls had more chances of being reported, which may have underestimated the result.

The higher occurrence of falls was observed among females, which is consistent with the findings in national and international literature ${ }^{1,8,9,14}$. Campbell et al. ${ }^{15}$, in a prospective study, examined the variables that increased the relative risk of women falling when 
Table 1. Occurrence of falls as the main accident reported in the past 12 months according to socioeconomic variables of individuals aged 60 years old or more. ISACAMP $2008(n=1,520)$.

\begin{tabular}{|c|c|c|c|c|}
\hline Variables & $\mathrm{n}(\%)$ & $\begin{array}{l}\text { Occurrence } \\
\text { of falls (\%) }\end{array}$ & PR $(95 \% \mathrm{Cl})$ & $\begin{array}{c}\text { Adjusted PR } \\
\text { (sex and/or age) } \\
(95 \% \mathrm{Cl})\end{array}$ \\
\hline \multicolumn{2}{|l|}{ Sex } & $0.0002^{*}$ & & \\
\hline Male & $616(42.8)$ & 3.4 & 1 & 1 \\
\hline Female & 904 (57.2) & 8.7 & $2.55(1.55-4.19)$ & $2.39(1.47-3.87)$ \\
\hline Total & $1520(100)$ & 6.5 & & \\
\hline \multicolumn{2}{|l|}{ Age } & $0.0012^{*}$ & & \\
\hline 60 to 69 years old & $821(54.0)$ & 4.6 & 1 & 1 \\
\hline 70 to 79 years old & $499(32.8)$ & 7.2 & $1.55(0.97-2.49)$ & $1.51(0.97-2.36)$ \\
\hline 80 years old or more & $200(13.2)$ & 12.5 & $2.70(1.71-4.28)$ & $2.50(1.61-3.88)$ \\
\hline \multicolumn{2}{|l|}{ Marital status } & $0.0000^{*}$ & & \\
\hline Married & $848(56.6)$ & 3.9 & 1 & 1 \\
\hline Widow(er) & $452(28.9)$ & 11.1 & $2.79(1.93-4.05)$ & $1.74(1.04-2.89)$ \\
\hline Other & $220(14.5)$ & 7.2 & $1.83(1.07-3.10)$ & $1.53(0.89-2.63)$ \\
\hline \multicolumn{2}{|l|}{ Schooling (years) } & $0.3319^{*}$ & & \\
\hline 0 to 3 & $547(34.8)$ & 7.8 & $1.61(0.80-3.26)$ & $1.18(0.62-2.25)$ \\
\hline 4 to 7 & $516(33.6)$ & 6.3 & $1.31(0.67-2.54)$ & $1.10(0.62-1.94)$ \\
\hline 8 to 11 & $100(6.6)$ & 6.9 & $1.43(0.55-3.75)$ & $1.42(0.58-3.44)$ \\
\hline 12 or more & $356(25.0)$ & 4.8 & 1 & 1 \\
\hline \multicolumn{2}{|l|}{ Paid occupation } & $0.1264^{*}$ & & \\
\hline No & $1202(78.6)$ & 6.9 & 1 & 1 \\
\hline Yes & $317(21.4)$ & 4.8 & $0.70(0.43-1.12)$ & $1.27(0.72-2.22)$ \\
\hline \multicolumn{2}{|c|}{$\begin{array}{l}\text { Family Income per capita (in minimum } \\
\text { wages) }\end{array}$} & $0.2770^{*}$ & & \\
\hline$<0.5$ & $241(15.7)$ & 9.0 & 1 & 1 \\
\hline 0.5 to 1 & $367(23.4)$ & 6.7 & $0.74(0.44-1.27)$ & $0.74(0.44-1.23)$ \\
\hline 1 to 4 & $738(48.6)$ & 5.4 & $0.60(0.32-1.12)$ & $0.63(0.33-1.17)$ \\
\hline$>4$ & $174(12.3)$ & 6.9 & $0.76(0.43-1.34)$ & $0.87(0.52-1.46)$ \\
\hline \multicolumn{2}{|l|}{ Type of household } & $0.4715^{*}$ & & \\
\hline House & $1302(84.8)$ & 6.6 & 1 & 1 \\
\hline Apartment & $186(13.4)$ & 5.1 & $0.78(0.46-1.31)$ & $0.85(0.51-1.39)$ \\
\hline Others & $32(1.8)$ & 9.2 & $1.39(0.41-4.66)$ & $1.53(0.59-3.98)$ \\
\hline
\end{tabular}

PR: prevalence ratio; $95 \% \mathrm{Cl}: 95 \%$ confidence interval; * $\mathrm{p}$ value in the $\chi^{2}$ test. 
Table 2. Occurrence of falls reported as the main accident in the past 12 months, according to health conditions, among individuals aged 60 years old or more. ISACAMP $2008(n=1,520)$.

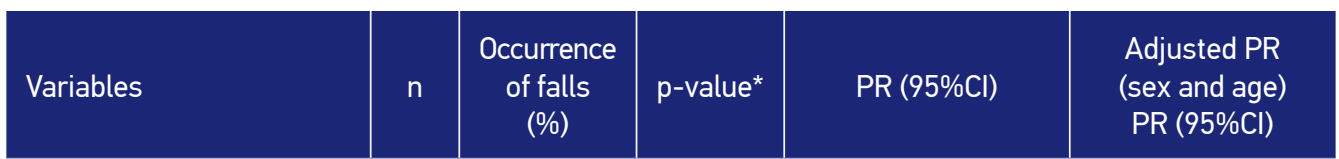

Chronic morbidities

\begin{tabular}{l|c|c|c|c|c}
\hline Hypertension & 819 & 7.4 & 0.1934 & $1.38(0.83-2.28)$ & $1.18(0.72-1.93)$ \\
\hline Diabetes & 333 & 5.1 & 0.2117 & $0.74(0.46-1.20)$ & $0.72(0.45-1.15)$ \\
\hline $\begin{array}{l}\text { Tumor/cancer } \\
\begin{array}{l}\text { Rheumatism/arthritis/ } \\
\text { arthrosis }\end{array}\end{array}$ & 81 & 6.0 & 0.8729 & $0.93(0.39-2.25)$ & $0.98(0.45-2.15)$ \\
\hline \begin{tabular}{l} 
Osteoporosis \\
\hline $\begin{array}{l}\text { Ashtma/bronchitis/ } \\
\text { emphysema }\end{array}$
\end{tabular} & 232 & 12.7 & 0.0000 & $2.42(1.66-3.53)$ & $1.71(1.18-2.49)$ \\
\hline $\begin{array}{l}\text { Tendinitis/repetitive } \\
\text { strain injury }\end{array}$ & 76 & 11.0 & 0.1259 & $1.77(0.80-3.92)$ & $1.74(0.81-3.74)$ \\
\hline \begin{tabular}{l} 
N. of chronic morbidities \\
\hline 0
\end{tabular} & 288 & 2.3 & 0.0042 & $1.98(1.23-3.17)$ & $1.73(1.09-2.74)$ \\
\hline 1 to 2 & 707 & 6.1 & & $2.57(1.13-5.83)$ & $2.17(0.98-4.80)$ \\
\hline 3 or more & 503 & 8.7 & & $3.68(1.52-8.92)$ & $2.57(1.08-6.12)$ \\
\hline
\end{tabular}

Health problems

\begin{tabular}{l|c|c|c|c|c}
\hline Headache & 290 & 9.1 & 0.0364 & $1.54(1.02-2.33)$ & $1.59(1.07-2.38)$ \\
\hline Backache & 667 & 7.5 & 0.1276 & $1.34(0.91-1.97)$ & $1.25(0.86-1.81)$ \\
\hline Dizziness & 294 & 14.1 & 0.0000 & $3.02(2.14-4.25)$ & $2.82(1.98-4.02)$ \\
\hline Insomnia & 349 & 10.7 & 0.0005 & $2.04(1.37-3.05)$ & $1.75(1.16-2.65)$ \\
\hline N. of Health Problems & & & 0.0000 & & \\
\hline 0 & 412 & 2.6 & & 1 & 1 \\
\hline 1 to 2 & 740 & 6.1 & & $2.29(1.19-4.42)$ & $2.19(1.18-4.04)$ \\
\hline 3 or more & 368 & 11.5 & & $4.26(2.23-8.13)$ & $3.63(1.94-6.76)$ \\
\hline $\begin{array}{l}\text { Common mental } \\
\text { disorder }\end{array}$ & 276 & 11.1 & 0.0009 & $2.03(1.34-3.08)$ & $1.72(1.12-2.64)$ \\
\hline
\end{tabular}


Table 3. Occurrence of falls reported as the main accident in the past 12 months, according to the use of medications and gait assistive devices among individuals aged 60 years old or more. ISACAMP $2008(n=1,520)$.

\begin{tabular}{|c|c|c|c|c|c|}
\hline Variables & $\mathrm{n}$ & $\begin{array}{l}\text { Occurrence } \\
\text { of falls } \\
(\%)\end{array}$ & p-value* & PR $(95 \% \mathrm{Cl})$ & $\begin{array}{c}\text { Adjusted PR } \\
\text { (sex and age) } \\
\text { PR }(95 \% \mathrm{Cl})\end{array}$ \\
\hline \multicolumn{3}{|l|}{ N. of medications } & 0.0027 & & \\
\hline 0 & 293 & 2.6 & & 1 & 1 \\
\hline 1 to 2 & 557 & 5.8 & & $2.17(0.88-5.32)$ & $1.86(0.81-4.27)$ \\
\hline 3 to 4 & 361 & 7.9 & & $2.97(1.24-7.12)$ & $2.19(0.99-4.86)$ \\
\hline 5 or more & 305 & 9.8 & & $3.70(1.55-8.80)$ & $2.50(1.12-5.56)$ \\
\hline Use a cane/walker & 99 & 17.2 & 0.0001 & $3.00(1.77-5.08)$ & $2.16(1.19-3.93)$ \\
\hline Using a wheelchair & 27 & 12.2 & 0.2266 & $1.91(0.54-6.71)$ & $1.81(0.64-5.12)$ \\
\hline
\end{tabular}

compared to men, and, even by controlling the effect of numberless variables, it was still observed that the risk among females was twice as high $(95 \%$ CI $1.40-2.92)$. Fried et al. ${ }^{16}$ considered that maybe women fall more often because of the lower amount of lean mass and muscle strength they present in relation to men at the same age group. According to Foldvari et al. ${ }^{17}$, women lose muscle strength earlier than men, getting closer to the limit in which power could compromise the functional status. Women would also be more exposed to extrinsic factors that cause sarcopenia (degenerative loss of mass and muscle strength) ${ }^{18}$, and they are also more exposed to household activities ${ }^{19,20}$.

The occurrence of falls was increasing with age, being 2.5 times more common among elderly people aged 80 years old or more in comparison to those aged 60 to 69 years old. This result is attributed to progressive balance loss and changes in muscle and bone mass, which take place during the aging process ${ }^{8,10,21}$. Studies have shown that one of the ways to minimize balance and muscle mass deficits that occur in this process is the regular practice of physical exercises ${ }^{22}$, which contributes with the improvement of functional capacity, balance, strength, coordination and movement velocity, thus promoting safer gait and preventing falls $\mathrm{s}^{18,23}$.

As to marital status, falls affected widows and widowers almost twice as much, even after adjustment for age and sex. Siqueira et al. ${ }^{10}$ consider that mutual care between partners could explain the lower occurrence of falls among those who live with a partner ${ }^{8}$. Studies by Perracini and Ramos ${ }^{1}$ and Siqueira et al. $^{8}$ also found increasing occurrence of falls for elderly widows and widowers, and authors analyze that the fact of living alone, which is more common in this condition, could lead the elderly person to have more tasks that, when associated with functional instability, would produce more situations connected to risks of falls. 
Table 4. Characteristics related to falls reported as the main accident in the past 12 months among individuals aged 60 years old or more according to sex. ISACAMP $2008(n=1,520)$.

\begin{tabular}{|c|c|c|c|c|}
\hline Variables & $\begin{array}{l}\text { Total } \\
\text { n (\%) }\end{array}$ & $\begin{array}{l}\text { Male } \\
\text { n (\%) }\end{array}$ & $\begin{array}{c}\text { Female } \\
\text { n (\%) }\end{array}$ & p-value \\
\hline Place of occurrence & & & & 0.9265 \\
\hline In the household & $64(64.0)$ & $13(61.6)$ & $51(64.6)$ & \\
\hline At work & $1(0.9)$ & $0(0.0)$ & $1(1.2)$ & \\
\hline In the street & $26(26.0)$ & $6(28.7)$ & $20(25.2)$ & \\
\hline Others & $9(9.1)$ & $2(9.7)$ & $7(9.0)$ & \\
\hline \multicolumn{4}{|l|}{ Limitation of current skills } & 0.7275 \\
\hline No & $43(43.3)$ & $10(47.1)$ & $33(42.2)$ & \\
\hline Yes & $57(56.7)$ & $11(52.9)$ & $46(57.8)$ & \\
\hline \multicolumn{4}{|l|}{ For how many days? } & 0.1335 \\
\hline One to two & $11(42.6)$ & $5(55.6)$ & $6(24.0)$ & \\
\hline Three or more & $23(57.4)$ & $4(44.4)$ & $19(76.0)$ & \\
\hline \multicolumn{4}{|l|}{ Need to be bedridden? } & 0.0956 \\
\hline No & $24(41.2)$ & $2(18.2)$ & $22(46.8)$ & \\
\hline Yes & $34(58.6)$ & $9(81.8)$ & $25(53.2)$ & \\
\hline \multicolumn{4}{|l|}{ For how many days? } & 0.0756 \\
\hline One to two & $14(41.2)$ & $6(66.7)$ & $8(32.0)$ & \\
\hline Three or more & $20(58.8)$ & $3(33.3)$ & $17(68.0)$ & \\
\hline \multicolumn{4}{|l|}{ Had medical care? } & 0.1863 \\
\hline No & $29(28.8)$ & $4(18.1)$ & $25(32.0)$ & \\
\hline Yes & 71 (71.2) & 17 (81.9) & $54(68.0)$ & \\
\hline
\end{tabular}

The frequency of falls reported as the main accident in the past 12 months significantly increased with the number of reported diseases and health problems. It is known that pains and health problems contribute with functional decline and increasing muscle weakness, associated with mobility limitations, and this may lead these people to be more prone to falls ${ }^{24,25}$.

Among the analyzed diseases, there was an association with rheumatism/arthritis/ arthroses and osteoporosis. A study conducted in Juiz de Fora, Minas Gerais ${ }^{9}$, also showed the association between osteoporosis and falls. Arthritis/arthrosis was also associated with falls in other studies ${ }^{5,12,16}$. Joint disorders and osteoporosis contribute with the reduced 
physical capacity of the elderly, causing pain, influencing balance and postural control, and increasing the risk of falls ${ }^{26}$.

Hypertension and diabetes are not associated with the occurrence of falls in this study, as observed in the study by Lin et al. ${ }^{14}$. Concerning diabetes, studies conducted in other countries ${ }^{27,28}$ found an association between this disease and falls, and report that the latter can be associated to complications related to diabetes, such as peripheral neuropathy, reduced vision, diabetic foot ulcers and damaged kidney function ${ }^{27}$.

Among the health problems, dizziness was mostly associated with the occurrence of falls. Bretan et al. ${ }^{29}$ also found an association between dizziness and the occurrence of falls among elderly attending an outpatient clinic in the city of Botucatu, São Paulo, as well as the cohort study by Moraes et al. ${ }^{30}$, conducted with the population of elderly people in Cuiabá, Mato Grosso, in which dizziness was present among 51\% of the individuals who reported falls in the past year.

It is important to emphasize that changes related to aging and systems related to body balance, as well as the higher prevalence of chronic degenerative diseases, and the chronic or multiple use of medications, among other factors, may favor the onset of dizziness or increase the intensity of this symptom, thus leading to more physical and functional limitations, and also emotional ones, in this age group, which contributes with the increasing risk of falls $\mathrm{s}^{31}$.

Insomnia was also identified as a factor associated with the occurrence of falls, as observed in other studies ${ }^{12,32}$. Insomnia represents the most common complaint related to changes in sleep among the elderly ${ }^{33}$. From the clinical point of view, these complaints are accompanied by damage in the performance of daytime activities, indicated by at least one of the following symptoms: fatigue or lack of energy, daytime sleepiness, attention, concentration and memory deficit, irritability, hyperactivity and aggression, reduced motivation, declining professional performance and social contacts ${ }^{34,35}$. Therefore, the clinical consequences of sleep-related problems among elderly people often result in increasing risk of accidents and traumas ${ }^{36}$.

CMD was also associated with the occurrence of falls. It is known that CMD is constituted by a set of psychiatric non-psychotic symptoms, characterized by somatic and depressive symptoms, state of anxiety, irritability, insomnia, fatigue, difficulties related to memory and concentration $^{37}$. Depression, which is included in the set of CMD symptoms, was studied by Rubenstein and Josephson ${ }^{38}$, who detected 2.2 more chances of falls among elderly with depression in comparison to elderly without depression. An analysis conducted in Sweden proves that stressful events, which awaken negative feelings, can be triggering factors for falls among older people ${ }^{39}$.

The association between asthma/bronchitis/emphysema and falls was observed in this study, however, it was not demonstrated in other studies ${ }^{1,27}$, since this association was not analyzed much ${ }^{40}$. Headache was also associated with falls among the elderly, however, no studies were found in literature demonstrating such an association. Studies ${ }^{41,42}$ report that asthma and headache contribute with more vulnerability and decreasing functional capacity. The use of medications, fewer social experiences and the feeling of discomfort associated with these conditions leads to changes in physical and mental mood for the 
performance of daily activities, so these aspects contribute with the establishment of a more vulnerable situation.

With regard to medications, it was observed that the higher the number of used medications, the higher the prevalence of falls. Hartikainen et al. ${ }^{43}$ mention that it is extremely important to investigate each of the drugs used individually or together, since many medications present adverse reactions that may induce to the occurrence of falls.

Rezende et $\mathrm{al} .{ }^{44}$, in a systematic review about falls and the use of medications among the elderly, observed that the drugs that are mostly associated with the occurrence of falls are psychoactive ones, due to their sedative effects, postural hypotension, shivers, muscle relaxation and weakness, and also the diuretics, due to fatigue and hydroelectrolytic disorder ${ }^{45}$.

With regard to the use of gait assistive devices, there was a significant association between the use of a cane/walker and the occurrence of falls, as reported in the study by Rubenstein and Josephson ${ }^{38}$. However, since this is a cross-sectional study, which ignores the date in which the gait assistive device began to be used, it is not possible to make causal inferences. It is a known fact that with age, individuals tend to walk slower, to reduce the pace and to increase the support base and time of permanence in the double support phase, as a strategy to gain stability ${ }^{46}$. Compromised gait among the elderly can increase the risk of falls ${ }^{47}$. Therefore, the technology assisted by assistive devices enables to promote more functional independence, thus facilitating the performance of daily activities by the elderly. This technology is employed to provide support while a person walks and balances, but it can also contribute to an unsafe mobility, thus increasing the risk of falls in case of project flaws and/or inadequate use ${ }^{48}$.

The most common place where falls occur was the household of the elderly person (64\%), followed by the streets (26\%). Studies show that falls happen mostly in the bedroom and in the bathroom ${ }^{49,30}$, and that facilitating factors that stand out in the house are rugs, wet floor, changes in the position of furniture, little light and staircases ${ }^{7}$. Therefore, it is important to assess the household environment and the extrinsic factors that contribute with the occurrence of falls, as well as ways to prevent them, such as the use of non-slippery flooring material, adequate lighting, absence of rugs, support bars, and others ${ }^{7,10}$.

Understanding and discussing the results obtained in this study should consider some limitations. One of them is the fact that the used question was not specific for falls, but instead, it was addressed to the occurrence of accidents in general, which included falls. So, we obtained data regarding the main accident, or the main fall that occurred in the past 12 months, which may have underestimated the results.

The collection of data about the fall being reported in the past 12 months may also be considered as a limitation, especially for the elderly, which could result in the subreport of events.

Another limitation lies on the cross-sectional design, which does not allow to infer on the causality of the association, as observed in relation to the association with a cane or walker and the use of medications. In this study, the past three days were used as reference, including continuous medication or not. It is also possible to consider that this study was 
based on data from a health survey that included more themes, so it was not specifically addressed to falls; therefore, there are not many details about the event.

By identifying the associated factors, this study indicates the segments of elderly people who are more prone to falls. Widow(ers), older and female elderly people, with joint disorders, asthma, headaches, dizziness and insomnia stand out. The presence of these characteristics and diseases should warn health professionals, caretakers and relatives of the elderly to pay special attention in terms of preventing falls. Using many medications, presenting with CMD and using equipment to gait assistive devices distinguish segments of elderly people into situations that require more care. By identifying these factors that are associated with falls, this study can contribute with the planning of public policies and health programs addressed to preventing falls and reducing their consequences.

\section{ACKNOWLEDGEMENTS}

To the National Council of Scientific and Technological Development for financial support (CNPq, process n. 409747 / 2006-8), and for the M.B.A productivity scholarship. To the Municipal Secretariat of Health of Campinas and to the Health Surveillance Secretariat, from the Ministry of Health, for the financial support for the field study of ISACamp 2008. To the Coordination for the Improvement of Higher Education Personnel (Capes) for the doctoral scholarship to I. G. Rodrigues.

\section{REFERENCES}

1. Perracini MR, Ramos LR. Fatores associados a quedas em uma coorte de idosos residentes na comunidade. Rev Saúde Pública 2002; 36(6): 709-16.

2. Brasil. Ministério da Saúde. Secretaria de Vigilância em Saúde. Departamento de Análise de Situação em Saúde. Saúde Brasil 2011: uma análise da situação de saúde e de evidências selecionadas de impacto de ações de vigilância em saúde. Brasília: Ministério da Saúde; 2012.

3. Cunha UG, Guimarães RM. Sinais e sintomas do aparelho locomotor. In: Guimarães RM, Cunha UG. Sinais e sintomas em geriatria. Rio de Janeiro: Revinter; 1989. p. 141-54.

4. Leite PF. Exercício, envelhecimento e promoção de saúde. Belo Horizonte: Editora Health; 1996. 125 p.

5. Gang L, Sufang J, Ying S. The incidence status on injury of the community-dwelling elderly in Beijing. Chi J Prev Med 2006; 40(1): 37.
6. Wannian L, Ying L, Xueqing W. An epidemiological study on injury of the community-dwelling elderly in Beijing. Chin J Dis Control Prev 2004; 8(6): 489-92.

7. Fabrício SCC, Rodrigues RAP, Costa Junior ML. Causas e consequências de quedas de idosos atendidos em hospital público. Rev Saúde Pública 2004; 38(1): 93-9.

8. Siqueira FV, Facchini LA, Silveira DS, Piccini RX, Tomasi E, Thumé E, et al . Prevalence of falls in elderly in Brazil: a countrywide analysis. Cad Saúde Pública 2011; 27(9): 1819-26.

9. Cruz DT, Ribeiro LC, Vieira MT, Teixeira MTB, Bastos RR, Leite ICG. Prevalência de quedas e fatores associados em idosos. Rev Saúde Pública 2012; 46(1): 138-46.

10. Siqueira FV, Facchini LA, Piccini RX, Tomasi E, Thumé E, Silveira DS, et al. Prevalência de quedas em idosos e fatores associados. Rev Saúde Pública 2007; 41(5): 749-56. 
11. Motta LB, Aguiar AC, Coutinho ESF, Huf G. Prevalência e fatores associados a quedas em idosos em um município do Rio de Janeiro. Rev Bras Geriatr Gerontol 2010; 13(1): 83-91.

12. Bekibele CO, Gureje O. Fall incidence in a population of elderly persons in Nigeria. Gerontology 2010; 56(3): 278-83.

13. Scazufca M, Menezes PR, Vallada H, Araya R. Validity of the self reporting questionnaire-20 in epidemiological studies with older adults: results from the Sao Paulo Ageing \& Health Study. Social Psychiatry Psychiatr Epidemiol 2009; 44(3): 247-54.

14. Lin CH, Liao KC, Pu SJ, Chen YC, Liu MS. Associated factors for falls among the community-dwelling older people assessed by annual geriatric health examinations. PLoS One 2011; 6(4): e18976.

15. Campbell AJ, Spears GF, Borrie MJ. Examination by logistic regression modelling of the variables which increase the relative risk of elderly women falling compared to elderly men. J Clin Epidemiol 1990; 42(13): 1415-20.

16. Fried LP, Tangen CM, Walston J, Newman AB, Hirsch C, Gottdiener J, et al. Frailty in older adults: evidence for a phenotype. J Gerontol A Biol Sci Med Sci 2001; 56(3): M146-56.

17. Foldvari M, Clark M, Laviolette LC, Bernstein MA, Kaliton D, Castaneda C, et al. Association of muscle power with functional status in community-dwelling elderly women. J Gerontol A Biol Sci Med Sci 2000; 55(4): M192-9.

18. Guimarães LHCT, Galdino DCA, Martins FLM, Vitorino DFM, Pereira KL, Carvalho EM. Comparação da propensão de quedas entre idosos que praticam atividade física e idosos sedentários. Rev Neurociênc 2004; 12(2).

19. Fleck AC, Wagner A. A mulher como a principal provedora do sustento econômico familiar. Psicol Estud 2003; 8(número especial): 31-8.

20. Rocha-Coutinho ML. Quando o executivo é uma "dama": a mulher, a carreira, e as relações familiares. In: Féres-Carneiro T (Org.). Família e casal: arranjos e demandas contemporâneas. Rio de Janeiro: Editora PUC-Rio; 2003. p. 15-30.

21. Coutinho ESF, Bloch KV, Rodrigues LC. Características e circunstâncias das quedas seguidas de fratura grave entre idosos no Rio de Janeiro, Brasil. Cad Saúde Pública 2009; 25(2): 455-9.

22. Yardley L, Beyer N, Hauer K, McKee K, Ballinger C, Tood C. Recommendations for promoting the engagement of older people in activities to prevent falls. Qual Saf Health Care 2007; 16(3): 230-4.

23. Alves Junior ED, Paula FL. A prevenção de quedas sob o aspecto da promoção da saúde. Fit Perf J 2008; 7(2): 123-9.
24. GuralnikJM, Fried LP, Salive ME. Disability as a public health outcome in the aging population. Annu Rev Public Health 1996; 17: 25-46.

25. Pérès K, Verret C, Alioum A, Barberger-Gateau P. The disablement process: factors associated with progression of disability and recovery in French elderly people. Disabil Rehabil 2005; 27(5): 263-76.

26. Barlett G, Abrahamowicz M, Grad R, Sylvestre MP, Tamblyn R. Association between risk factors for injurious falls and new benzodiazepine prescribing in elderly persons. BMC Fam Pract 2009; 10:1.

27. Masud T, Morris RO. Epidemiology of falls. Age Aging 2001; 30(Suppl 4): 3-7.

28. Gregg EW, Beckles GL, Williamson DF, Leveille SG, Langlois JA, Engelgau MM, et al. Diabetes and physical disability among older U.S. adults. Diabetes Care 2000; 23(9): 1272-7.

29. Bretan O, Silva Junior JE, Ribeiro OR, Corrente JE. Risco de queda em idosos da comunidade: avaliação com o teste Timed up and go. Braz J Othorhinolaryngol 2013; 79(1): 18-21.

30. Moraes SA, Soares WJS, Rodrigues RAS, Fett WCR, Ferriolli E, Perracini MR. Tontura em idosos da comunidade: estudo de base populacional. Braz J Otorhinolaryngol 2011; 77(6): 691-9.

31. Gazzola JM, Ganança FF, Aratani MC, Perracini MR, Ganança MM. Caracterização clínica de idosos com disfunção vestibular crônica. Rev Bras Otorrinolaringol 2006; 72(4): 515-22.

32. Pereira AA, Ceolim MF, Neri AL. Associação entre sintomas de insônia, cochilo diurno e quedas em idosos da comunidade. Cad Saúde Pública 2013; 29(3): 535-46.

33. Stone KL, Ensrud KE, Ancoli-Israel S. Sleep, insomnia and falls in elderly patients. Sleep Med 2008; 9(Suppl 1): S18-22.

34. Vaz Fragoso CA, Gill TM. Sleep complaints in community-living older persons: a multifactorial geriatric syndrome. J Am Geriatr Soc 2007; 55(11): 1853-66.

35. Edinger JD, Bonnet MH, Bootzin RR, Doghramji K, Dorsey CM, Espie CA, et al. Derivation of research diagnostic criteria for insomnia: report of an American Academy of Sleep Medicine Work Group. Sleep 2004; 27(8): 1567-96.

36. Ancoli-Israel S. Sleep and its disorders in aging populations. Sleep Med 2009; 10(Suppl 1): S7-11.

37. Goldberg D, Huxley P. Common mental disorders: a biosocial model. London: Tavistock; 1992.

38. Rubenstein LZ, Josephson KR. The epidemiology of falls and syncope. Clin Geriatr Med 2002; 18(2): 141-58. 
39. Möller J, Hallqvist J, Laflamme L, Mattsson F, Ponzer S, Sadigh S, et al. Emotional stress as a trigger of falls leading to hip or pelvic fracture. Results from the ToFa study - a case-crossover study among elderly in Stockholm, Sweden. BMC Geriatr 2009; 9: 7.

40. National Center for Health Statistics. National Health Interview Survey (NHIS). Public use core file layouts. Guidelines. 1989.

41. Rosa TEC, Benício MHD, Latorre MRDO, Ramos LR. Fatores determinantes da capacidade funcional entre idosos. Rev Saúde Pública 2003; 37(1): 40-8.

42. Dellaroza MSG, Pimenta CAM, Matsuo T. Prevalência e caracterização da dor crônica em idosos não institucionalizados. Cad Saúde Pública 2007; 23(5): 1151-60.

43. Hartikainen S, Lönnroos E, Louhivuori K. Medication as a risk factor for falls: critical systematic review. J Gerontol A Biol Sci Med Sci 2007; 62(10): 1172-81.

44. Rezende CP, Gaede-Carrillo MRG, Sebastião ECO. Queda entre idosos no Brasil e sua relação com o uso de medicamentos: revisão sistemática. Cad Saúde Pública 2012; 28(12): 2223-35.
45. Rozenfeld S. Reações adversas aos medicamentos na terceira idade: as quedas em mulheres como iatrogenia farmacoterapêutica [tese de doutorado]. Rio deJaneiro: Instituto de Medicina Social, Universidade do Estado do Rio de Janeiro;1997.

46. Menz HB, Lord SR, Fitzpatrick RC. Age-related differences in walking stability. Age Ageing 2003; 32(2): 137-42.

47. Cesari M, Onder G, Russo A, Zamboni V, Barrillaro C, Ferrucci L, et al. Comorbidity and physical function: results from the aging and longevity study in the Sirente geographic area (ilSIRENTE study). Gerontology 2006; 52(1): 24-32.

48. Menezes RL, Bachion MM. Estudo da presença de fatores de riscos intrínsecos para quedas, em idosos institucionalizados. Ciênc Saúde Colet 2008; 13(4): 1209-18.

49. Costa Neto MM. Atenção à saúde do idoso, instabilidade postural equeda. In: Ministério da Saúde. Secretaria de Políticas de Saúde. Departamento de Atenção Básica. Cadernos de Atenção Básica. Brasília: Ministério da Saúde; 2000.

50. Abrans WB, Berkow R. Manual Merck de Geriatria. São Paulo: Roca; 1995.

Received on: 08/06/2013

Final version presented on: 01/16/2014

Accepted on: 02/18/2014 